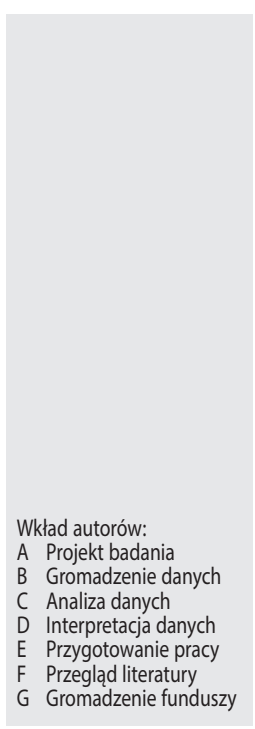

\title{
Refluks krtaniowo-gardłowy w chorobach laryngologicznych u dzieci
}

\section{Laryngopharyngeal reflux in laryngological disorders in children}

\author{
Ewa Dołęgowska ${ }^{1}$, Elżbieta Włodarczyk² ${ }^{2}$ Edyta Piłka ${ }^{3}$ \\ ${ }^{1}$ Szpital Wojewódzki im. Kardynała Stefana Wyszyńskiego w Łomży, Odział \\ Otolaryngologiczny, Łomża \\ ${ }^{2}$ Instytut Fizjologii i Patologii Słuchu, Światowe Centrum Słuchu, Klinika Rehabilitacji, \\ Warszawa/Kajetany \\ ${ }^{3}$ Instytut Fizjologii i Patologii Słuchu, Światowe Centrum Słuchu, Zakład Audiologii \\ Eksperymentalnej, Warszawa/Kajetany
}

\begin{abstract}
Streszczenie
Refluks krtaniowo-gardłowy (LPR) stanowi szczególną postać refluksu żołądkowo-przełykowego, w której płynna i gazowa treść żołądkowa dociera do górnego odcinka układu oddechowego i przewodu pokarmowego. LPR jest coraz częściej rozpoznawanym problemem zdrowotnym w populacji dziecięcej, szczególnie przy współistnieniu innych chorób laryngologicznych. Ze względu na powodowane dolegliwości schorzenie to znajduje się w sferze zainteresowań otolaryngologów, foniatrów, chirurgów, pulmonologów, stomatologów, pediatrów, gastrologów i kardiologów dziecięcych.

Słowa kluczowe: refluks krtaniowo-gardłowy • choroby laryngologiczne $\bullet$ choroby laryngologiczne u dzieci
\end{abstract}

\begin{abstract}
Laryngopharyngeal reflux (LPR) is a specific type of gastroesophageal reflux in which fluid and gas gastric contents flow into the upper digestive and respiratory tract. LPR is increasingly often diagnosed in the pediatric population, especially coexisting with other laryngological disorders. Due to the symptoms it causes, the disease falls into the scope of interest of otolaryngologists, phoniatricians, surgeons, pulmonologists, dentists, gastrologists, and pediatric cardiologists.
\end{abstract}

Key words: laryngopharyngeal reflux $\bullet$ LPR $\bullet$ ENT disorders $\bullet$ pediatric ENT disorders

\section{Wprowadzenie}

Refluks krtaniowo-gardłowy (ang. laryngopharyngeal reflux, LPR) stanowi szczególną postać refluksu żołądkowo-przełykowego (ang. gastroesophageal reflux, GERD), w której płynna i gazowa treść żołądkowa dociera do górnego odcinka układu oddechowego i przewodu pokarmowego (w pozycji stojącej, w ciągu dnia) [1]. LPR określany jest mianem niemego, cichego oraz atypowego z uwagi na to, że objawy gastryczne, takie jak: zgaga, odbijanie, nudności, wymioty czy ulewanie, nie występują albo występują bardzo rzadko [1].

LPR jest coraz częściej rozpoznawanym problemem zdrowotnym w populacji dziecięcej. Ze względu na powodowane dolegliwości schorzenie to znajduje się w sferze zainteresowań otolaryngologów, foniatrów, chirurgów, pulmonologów, stomatologów, pediatrów, gastrologów i kardiologów dziecięcych.

Niewielkie, subkliniczne dolegliwości mogą doprowadzić do wielu powikłań, między innymi zapalenia krtani, gardła, nosa, zatok albo ucha środkowego. Może to mieć wpływ na codzienne funkcjonowanie dziecka oraz na jego rozwój społeczny. Pojawiający się niedosłuch oraz problemy z mową mogą potęgować niepokój, rozdrażnienie, obniżenie koncentracji, obniżenie wyników w szkole oraz zaniżać samoocenę [2-4].

Adres autora: Ewa Dołęgowska, Oddział Laryngologiczny, Szpital Wojewódzki im. Kardynała Stefana Wyszyńskiego w Łomży, al. Marszałka Jozefa Piłsudskiego 11, 18-404 Łomża; e-mail: ewa.laryng@gmail.com 
LPR u dzieci objawia się najczęściej dolegliwościami ze strony górnych dróg oddechowych, takimi jak chrząkanie, a nawet suchy przewlekły kaszel, świszczący oddech, duszność, chrypka (szczególnie poranna), dysfonia, suchość w jamie ustnej i gardle, uczucie przeszkody w gardle oraz spływanie wydzieliny po tylnej ścianie gardła. Ponadto może wystąpić odczucie nadmiernego pragnienia oraz ślinienie się, odkrztuszanie, ból ucha, szyi i gardła. Dodatkowym objawem jest nieprzyjemny zapach z ust, stan zapalny zatok czy krtani oraz dławienie się, dysfagia, zatykanie uszu, a także symptomy astmy oskrzelowej [5].

W patomechanizmie refluksu główną rolę odgrywa dysfunkcja górnego zwieracza przełyku, mniejsza oporność błony śluzowej gardła i krtani, a tym samym znacznie większa wrażliwość błon śluzowych na ekspozycję treści żołądkowej z powodu małej aktywności anhydrozy węglanowej, a także skurcz krtani i oskrzeli na drodze odruchu z nerwu błędnego w wyniku drażnienia dolnej części przełyku [1]. Błona śluzowa krtani ma znacznie słabiej rozwinięte mechanizmy obronne niż przełyk i nie jest w stanie zneutralizować działania czynników uszkadzających. Dlatego też konsekwencją uszkodzeń błony mogą być owrzodzenia, ziarninowania i zwężenia podgłośniowego krtani [6].

W obrazie laryngoskopowym krtani w refluksowym zespole krtaniowym obserwowane są stany zapalne tylnego odcinka krtani (możliwy obrzęk) [7], a także guzki głosowe [8]. U dzieci najczęściej obserwuje się obrzęk strun głosowych i owrzodzenie kontaktowe [9].

Wyróżniane są dwa mechanizmy powstawania pozaprzełykowych objawów choroby refluksowej - bezpośredni i pośredni. Mechanizm bezpośredni, zwany mikroaspiracją treści refluksowej, polega na bezpośrednim podrażnieniu błony śluzowej gardła oraz krtani, czego skutkiem jest tchawiczo-oskrzelowy odruch kaszlowy. Z uwagi na to, że krtań i gardło mają odmienną niż przełyk budowę histologiczną oraz odmienny mechanizm obronny błony śluzowej, uszkodzenie błony śluzowej krtani może być nieodwracalne [10-11]. Mechanizm pośredni to odruch realizowany za pośrednictwem nerwu błędnego. Następstwem podrażnienia chemoreceptorów w przełyku jest: odruch kaszlowy, odchrząkiwanie, skurcz oskrzeli oraz nasilenie miejscowych procesów zapalnych. Reakcją na podrażnienie chemoreceptorów kwaśną treścią o $\mathrm{pH}$ poniżej 2,5 jest odruchowy skurcz głośni, czyli laryngospazm [12]. Nagłe i silne zamkniecie głośni, skurcz fałdów nalewkowo-nagłośniowych i zwężenie oskrzeli są czynnościowymi konsekwencjami refluksu [13].

Celem pracy jest przedstawienie chorób laryngologicznych, w których znaczącą rolę odgrywa refluks krtaniowo-gardłowy.

\section{Choroby laryngologiczne}

\section{Laryngomalacja}

Jest to wrodzona wiotkość krtani, w wyniku której dochodzi do zapadania się tkanek i obturacji górnych dróg oddechowych. W większości przypadków dolegliwość nie wymaga interwencji - mija samoistnie. Objawia się świszczącym stridorem, czyli świstem krtaniowym przy nabieraniu powietrza. Ponadto występuje kaszel, krztuszenie się oraz ulewanie [14]. Badania Hartla i Chadha [15] pokazują, że $65 \%$ badanych dzieci z ciężką laryngomalacją miało refluks, natomiast występował on znacznie rzadziej przy łagodnej postaci. Thompson [16] podaje, że u $89 \%$ pacjentów z umiarkowanym i ostrym stadium wiotkości krtani, po ponad 7 miesiącach leczenia farmakologicznego refluksu kaszel i krztuszenie się ustępują. Ponadto po farmakoterapii zmniejsza się zarzucania treści żołądkowej, co odnotowano u 70\% dzieci [16]. W pracy Matthews i wsp. [17] wykazano stuprocentową korelację między laryngomalacją a refluksem, gdzie LPR definiowany był jako co najmniej 1 epizod $\mathrm{pH}$ poniżej 4 (prawidłowe pH od 4 do 7) przez co najmniej 4 sekundy. Little i in. [18] wykazali, że prawie połowa pacjentów z refluksem pozaprzełykowym została prawidłowo zdiagnozowana dopiero po 24-godzinnym dwusondowym jednoczesnym monitorowaniu $\mathrm{pH}$ w przełyku i gardle. Jednakże nie wszystkie prezentowane w literaturze wyniki dotyczące laryngimalacji są tak jednoznaczne [19-21]. Niektórzy badacze uważają, że zmniejszenie objawów tej choroby wynika $\mathrm{z}$ naturalnego rozwoju dziecka wraz z wiekiem [22].

\section{Ziarniniaki krtani}

Region wyrostka głosowego jest szczególnie wrażliwy na urazy powodowane uderzaniem o siebie tych struktur. W następstwie takiej traumy rozwija się reakcja zapalna, owrzodzenie i martwica chrząstki. Reaktywne ziarninowanie jest odpowiedzią na kolejne mechaniczne urazy i kwaśne refluksy [13]. Aktualnie refluks krtaniowo-gardłowy uważany jest za najważniejszy czynnik etiologiczny ziarniniaka krtani [13]. W populacji dzieci nie przeprowadzono dotychczas badań, które potwierdziłyby powyższą zależność [21].

\section{Podgłośniowe zwężenie krtani}

Zwężenie krtani najczęściej powstaje w wyniku powikłań po intubacji czy tracheotomii. Ograniczenie światła dróg oddechowych prowadzi do duszności oraz zaburzeń głosu. Ponadto mogą tworzyć się ziarniniaki pointubacyjne [23]. Przypadłość ta występuje u ok. 10-40\% wcześniaków wentylowanych mechanicznie [24].

Badania pokazują, że przyczyną tej choroby może być także LPR [25], który negatywnie oddziałuje na uszkodzoną błonę śluzową, co w konsekwencji prowadzi do odrastania ziarniniaków. Pokazano to na modelu zwierzęcym [26]. Badania prowadzone w populacji dziecięcej ze zwężeniem podgłośniowym krtani pokazują, że u większości z nich występował również refluks [27-31]. Halstead i in. [27] wykazali, że jedna trzecia badanych dzieci z tym schorzeniem leczonych z powodu refluksu uniknęła interwencji chirurgicznej.

\section{Guzki głosowe fałdów głosowych}

Są to łagodne zmiany na obu fałdach głosowych. Powstają w wyniku niewłaściwej emisji głosu - hyperfunkcjonalnej dysfonii, tzn. wzmożonego napięcia mięśni podczas fonacji u dzieci nadpobudliwych. Block i in. [32] opisują, że zastosowanie u dzieci, u których przyczyną chrypki 
były guzki głosowe, jednoczasowego leczenia przeciwrefluksowego i terapii głosu jest efektywniejsze niż oparcie się tylko na terapii głosu. Zwiększenie masy fałdów głosowych skutkuje obniżeniem wysokości głosu (F0) oraz obniżeniem i zawężeniem skali głosu [13].

\section{Pseudorowek krtani - obrzęk podgłośniowy}

Obrzęk podgłośniowy rozciąga się od spoidła przedniego do tylnej okolicy krtani. Ma to znaczenie w diagnostyce różnicowej z rowkiem głośni, który nie przekracza wyrostka głosowego i występuje w środkowej części strefy międzywięzadłowej fałdu głosowego [13]. Badania Carra i in. [30] pokazały, że z 66 dzieci poddanych laryngoskopii bezpośredniej z powodu objawów obrzęku podgłośniowego - 56 miało pozytywny wynik testu refluksowego. Natomiast $70 \%$ dzieci z ujemnymi wynikami testów Refluksowych (całodobowe monitorowanie $\mathrm{pH}$, scyntygrafia żołądka, połykanie baru i biopsja przełyku) nie miało pseudorowka krtani.

\section{Brodawczaki górnych dróg oddechowych}

Brodawczak jest łagodną zmianą rosnąca egzofitycznie na błonach śluzowych wywołaną przez wirusy brodawczaków ludzkich (HPV); w przypadku krtani - głównie przez HPV 6 i HPV 11 niskoonkogenne [33-36]. Badania wykazały, że późne powikłania związane z leczeniem nawracających brodawczaków krtani, takie jak blizny i zwężenia dróg oddechowych, występują częściej u dzieci z refluksem; Ponadto leczenie przeciwrefluksowe po operacjach brodawczaków krtani redukuje ilość powikłań [37]. Inne badania pokazują, że u dzieci z łagodną i umiarkowaną postacią refluksu krtaniowo-gardłowego dzięki terapii przeciwrefluksowej nastąpiła poprawa lub nawet ustąpienie choroby brodawczakowej [38, 39].

\section{Kurcz krtani - laryngospazm}

Napadowy skurcz krtani może być wynikiem bezpośredniej aspiracji treści refluksowej pogarszającej wymianę gazową albo odruchu z chemoreceptorów krtaniowych gardła lub przełyku [40]. Kurcz krtani indukowany refluksem objawia się dusznością ze stridorem, który jest skutkiem szybko narastającego obrzęku błony śluzowej przedsionka krtani spowodowanego zarzucaniem kwaśnej treści refluksowej. W następstwie wywołanego odruchu dośrodkowego nerwów krtaniowych górnych pojawia się bezdech, podciśnienie tętnicze oraz skurcz naczyń obwodowych. Patologiczny refluks jest potencjalnym czynnikiem ryzyka laryngospazmu i w konsekwencji nagłej śmierci niemowląt [41].

\section{Przewlekłe zapalenie zatok}

Związek refluksu z zapaleniem zatok wynika z indukowania przez LPR zmian zapalnych błony śluzowej nosogardła i nosa, co prowadzi do zmienionej adherencji bakterii, zaburzeń transportu śluzówkowo-rzęskowego oraz zaburzeń drenażu limfatycznego. W konsekwencji dochodzi do obrzęku okolicy ujść zatok i nosa [40]. Badania Barbero [42] wykazały, że u dzieci objawy rynologiczne ustępowały po 3 miesiącach leczenia przeciwrefluksowego. Istnienie zależności pomiędzy występowaniem refluksu i stanów zapalnych zatok potwierdzają inni autorzy [np. 43].

\section{Przerost migdałka gardłowego}

Refluks krtaniowo-gardłowy jest czynnikiem inicjującym zmiany zapalne, obrzękowe i wzrost sekrecji w obrębie błony śluzowej nosogardła [44]. Badania z wykorzystaniem $\mathrm{pH}$-metrii $\mathrm{z}$ podwójną sondą przeprowadzone $\mathrm{u}$ dzieci z przerostem migdałka gardłowego potwierdziły obecność LPR u ok. 50\% badanych [45].

\section{Wysiękowe zapalenie ucha środkowego}

Jest to choroba zapalna wyściółki trąbki słuchowej, jamy bębenkowej oraz komórek powietrznych wyrostka sutkowatego. Charakterystyczne jest gromadzenie się płynu wysiękowego w jamie bębenkowej ucha środkowego [46]. Współistniejący refluks krtaniowo-gardłowy przyczynia się do utrzymywania się stanu zapalnego [1], szczególnie u dzieci, ponieważ trąbka słuchowa ma u nich inny kształt niż u osób dorosłych. W badaniach dotyczących składu płynów wysiękowych ucha środkowego u dzieci stwierdzono obecność pepsyny pochodzącej z refluksu treści żołądkowej [1].

\section{Podsumowanie}

Celem niniejszej pracy było zwrócenie uwagi na to, że wielu chorobach laryngologicznych występujących u dzieci znaczącą rolę odgrywa refluks krtaniowo-gardłowy. Na podstawie literatury wykazano, że u podstaw dobrej diagnozy i skutecznej terapii leży przede wszystkim interdyscyplinarne podejście do problemu, z jakim zgłosił się pacjent, czyli połączenie i wykorzystanie wiedzy z zakresu pediatrii, pulmonologii, alergologii, gastrologii i laryngologii. Ma to szczególne znaczenie u dzieci, ponieważ nieprawidłowa lub przedłużająca się diagnoza może u nich skutkować powikłaniami, np. niedosłuchem, który w znacznym stopniu wpływa na jakość ich życia (niedosłuch najczęściej powstaje w przypadku przewlekłych schorzeń górnych dróg oddechowych). Ważna jest edukacja zwiększająca świadomość na ten temat nie tylko wśród lekarzy, lecz przede wszystkim rodziców i samych dzieci, z uwagi na fakt, że leczenie LPR polega nie tylko na podawaniu środków farmakologicznych, lecz także na zmianie nawyków żywieniowych czy poprawie higieny snu (uniesienie wezgłowia łóżka podczas snu dziecka).

\section{Piśmiennictwo}

1. Dymek A, Dymek L. Refluks krtaniowo-gardłowy. Warszawa: Wydawnictwo Lekarskie PZWL; 2015.

2. Moore BCJ. Wprowadzenie do psychologii słyszenia. Warszawa: Wydawnictwo Naukowe PWN; 1999.
3. Narząd głosu i jego znaczenie w komunikacji społecznej. Obrębowski A (red.). Poznań: Wydawnictwo Naukowe Uniwersytetu Medycznego im. Karola Marcinkowskiego; 2008.

4. Wybrane zagadnienia $z$ audiometrii mowy. Obrębowski A (red). Poznań: Wydawnictwo Naukowe Uniwersytetu Medycznego im. Karola Marcinkowskiego; 2011. 
5. Galluzzi F, Schindler A, Gaini R, Garavello W. The assessment of children with suspected laryngopharyngeal reflux: An Otorhinolaryngological perspective. Int J Pediatr Otorhinolaryngol, 2015; 79(10): 1613-9.

6. Koufman JA. The otolaryngologic manifestations of gastroesophageal reflux disease (GERD): clinical investigation of 225 patients using ambulatory 24 -hour $\mathrm{pH}$ monitoring and an experimental investigation of the role of acid and pepsin in the development of laryngeal injury. Laryngoscope, 1991; 101 (Suppl. 53): 1-78.

7. McMurray J, Gerber M, Stern Y, Walner D, Rudolph D, Willging JP i wsp. Role of laryngoscopy, dual $\mathrm{pH}$ probe monitoring, and laryngeal mucosal biopsy in the diagnosis of pharyngoesophageal reflux. Ann Otol Rhinol Laryngol, 2001; 110(4): 299-304.

8. Skrzypczak W, Kowalska B. Zmiany w krtani w przebiegu choroby refluksowej. Ann Acad Med Gedan, 2011; 41: 115-23.

9. Hicks D, Ours T, Abelson T, Vaezi MF, Richter JE. The prevalence of hypopharynx findings associated with gastroesophageal reflux in normal volunteers. J Voice, 2002; 16(4): 564-79.

10. Axford SE, Sharp N, Ross PE, Pearson JP, Dettmer PW, Panetti M, Koufman JA. Cell biology of laryngeal epithelial defenses in health and disease: preliminary studies. Ann Otol Rhinol Laryngol, 2001; 110(12): 1099-108.

11. Johnston N, Bulmer D, Gill GA, Panetti M, Ross PE, Pearson JP, Pignatelli M, Axford SE, Dettmar PW, Koufman JA. Cell biology of laryngeal epithelial defenses in health and disease: further studies. Ann Otol Rhinol Laryngol, 2003; 112(6): 481-91.

12. Loughlin CJ, Koufman JA. Paroxysmal laryngospasm secondary to gastroesophageal reflux. Laryngoscope, 1996; 106(12): $1502-5$.

13. Domeradzka-Kołodziej A. Refluks krtaniowo-gardłowy w praktyce foniatrycznej. Otolaryngol Pol, 2013; 2(3): 159-64.

14. Holinger LD. Etiology of stridor in the neonate, infant and child. Ann Otol Rhinol Laryngol, 1980; 89(5): 397-400.

15. Hartl TT, Chadha NK. A systematic review of laryngomalacia and acid reflux. Otolaryngol Head Neck Surg, 2012; 147(4): $619-26$.

16. Thompson DM. Abnormal sensorimotor integrative function of the larynx in congenital laryngomalacia: a new theory of etiology. Laryngoscope, 2007; 117(6 Pt 2 Suppl. 114): 1-33.

17. Matthews BL, Little JP, Mcguirt WF Jr, Koufman JA. Reflux in infants with laryngomalacia: results of 24-hour double-probe $\mathrm{pH}$ monitoring. Otolaryngol Head Neck Surg, 1999; 120(6): 860-4.

18. Little JP, Matthews BL, Glock MS, Koufman JA, Reboussin DM, Loughlin CJ i wsp. Extraesophageal pediatric reflux: 24-hour double-probe $\mathrm{pH}$ monitoring of 222 children. Ann Otol Rhinol Laryngol Suppl., 1997; 169: 1-16.

19. Iyer VK, Pearman K, Raafat F. Laryngeal mucosal histology in laryngomalacia: the evidence for gastroesophageal reflux laryngitis. Int J Pediatr Otorhinolaryngol, 1999; 49(3): 225-30.

20. Chandra RK, Gerber ME, Holinger LD. Histological insight into the pathogenesis of severe laryngomalacia. Int J Pediatr Otorhinolaryngol, 2001; 61(1): 31-8.

21. Venkatesan NN, Pine HS, Underbrink M. Laryngopharyngeal reflux disease in children. Pediatr Clin North Am, 2013; 60(4): $865-78$.

22. Thompson DM. Laryngomalacia: factors that influence disease severity and outcomes of management. Curr Opin Otolaryngol Head Neck Surg, 2010; 18(6): 564-70.

23. Karkos PD, Leong SC, Apostolidou MT, Apostolidis T. Laryngeal manifestations and pediatric laryngopharyngeal reflux. Am J Otolaryngol, 2006; 27(3): 200-3.
24. Durlak W, Kwinta P. Odległe następstwa wcześniactwa związane z układem oddechowym. Pediatria po Dyplomie, 2017; 1.

25. Szyfter W, Wierzbicka M, Gawęcki W, Popko M, Leszczyńska M, Balcerowiak A. Przyczyny zwężeń krtaniowo-tchawiczych na podstawie przeglądu literatury i doświadczeń własnych. Otolaryngol Pol, 2009; 63(4): 338-42.

26. Delahunty JE, Cherry J. Experimentally produced vocal cord granulomas. Laryngoscope, 1968; 78(11): 1941-7.

27. Halstead LA. Gastroesophageal reflux: a critical factor in pediatric subglottic stenosis. Otolaryngol Head Neck Surg, 1999; 120(5): 683-8

28. Yellon RF, Coticchia J, Dixit S. Esophageal biopsy for the diagnosis of gastroesophageal reflux-associated otolaryngologic problems in children. Am J Med, 2000; 108 (4 Suppl. 1): 131-8.

29. Carr MM, Nagy ML, Pizzuto MP, Poje CP, Brodsky LS. Correlation of findings at direct laryngoscopy and bronchoscopy with gastroesophageal reflux disease in children: a prospective study. Arch Otolaryngol Head Neck Surg, 2001; 127(4): 369-74.

30. Carr MM, Abu-Shamma U, Brodsky LS. Predictive value of laryngeal pseudosulcus for gastroesophageal reflux in pediatric patients. Int J Pediatr Otorhinolaryngol, 2005; 69(8): 1109-12.

31. Mitzner R, Brodsky L. Multilevel esophageal biopsy in children with airway manifestations of extraesophageal reflux disease. Ann Otol Rhinol Laryngol, 2007; 116(8): 571-5.

32. Block BB, Brodsky L. Hoarseness in children: The role of laryngopharyngeal reflux. Int J Pediatr Otorhinolaryngol, 2007; 71(9): 1361-569.

33. Szyfter K, Wierzbicka M. Rola wirusa brodawczaka (HPV) w nowotworach głowy i szyi. Postępy w Chirurgii Głowy i Szyi, 2008; 2(7): 41-50.

34. Gilson ML, Koch WM, Capone RB, Spafford M, Westra WH, Wu L i wsp. Evidence for a casual association between human papillomavirus and a subset of head and neck cancers. J Natl Cancer Inst, 2000; 92(9): 709-20.

35. Morshed K. Udział wirusa brodawczaka ludzkiego (HPV) w etiopatogenezie nowotworów głowy i szyi. Otolaryngologia, 2004; 3(3): 91-6.

36. Nowaczewska K, Wójtowicz P, Kukwa A, Ratajczak J, Tulibacki M. Brodawczaki górnych dróg oddechowych - nowe metody leczenia. Otolaryngol Pol, 2010; 64(1): 31-6.

37. Holland BW, Koufman JA, Postma GN, McGuirt WF Jr. Laryngopharyngeal reflux and laryngeal web formation in patients with pediatric recurrent respiratory papillomas. Laryngoscope, 2002; 112(11): 1926-9.

38. McKenna M, Brodsky L. Extraesophageal acid reflux and recurrent respiratory papillomatosis in children. Int J Pediatr Otorhinolaryngol, 2005; 69(5): 597-605.

39. Borkowski G, Sommer P, Stark T, Sudhoff H, Luckhaupt H. Recurrent respiratory papillomatosis associated with gastroesophageal reflux disease in children. Eur Arch Otorhinolaryngol, 1999; 256(7): 370-2.

40. Otorynolaryngologia praktyczna. Podręcznik dla studentów i lekarzy, t. 2. Janczewski G (red.). Gdańsk: Via Medica; 2005.

41. Bielecki I, Mniszek J, Woś H. Aspekty laryngologiczne refluksu żołądkowo-przełykowego u dzieci. Chirurgia Polska, 2004; 6(1): 51-63.

42. Barbero GJ. Gastroesophageal reflux and upper airway disease. Otolaryngol Clin North Am, 1996; 29(1): 27-38.

43. Weaver EM. Association between gastroesophageal reflux and sinusitis, otitis media, and laryngeal malignancy: a systematic review of the evidence. Am J Med, 2003; 115 (Suppl. 3A): 81-9. 
44. Tumgor G, Midilli R, Yuksekkaya HA, Cakir M, Ozgenc F, Yagci RV. Laryngopharyngeal reflux in patients with severe adeno-tonsil hyperplasia. Int J Pediatr Otorhinolaryngol, 2006; 70(4): 761-2.
45. Keles B, Ozturk K, Arbag H, Gunel E, Ozer B. Frequency of pharyngeal reflux in children with adenoid hyperplasia. Int J Pediatr Otorhinolaryngol, 2005; 69(8): 1103-7.

46. Audiologia kliniczna. Śliwińska-Kowalska M (red.). Łódź: Mediton; 2005. 